\title{
PENDAMPINGAN PADA PASANGAN USIA SUBUR DALAM PENGGUNAAN KONTRASEPSI SEBAGAI UPAYA MENEKAN UNMET NEED KB DI MASA ADAPTASI KEBIASAAN BARU
}

\author{
Kadek Widiantari'1), Ni Made Rai Widiastuti'2) \\ 1)Program Studi Profesi Bidan, Politeknik Kesehatan Kartini Bali, Denpasar, Bali \\ 2)Program Studi Sarjana Terapan Kebidanan, Politeknik Kesehatan Kartini Bali, Denpasar, Bali \\ Corresponding author: Kadek Widiantari \\ E-mail : diantari808@gmail.com
}

Diterima 26 November 2021, Disetujui 02 Desember 2021

\begin{abstract}
ABSTRAK
Tingginya angka unmet need bukan hanya menjadi permasalahan dalam program KeluargaBerencana di Indonesia, namun juga dihadapai oleh tiap belahan dunia. Kelompok unmet need merupakan sasaran yang perlu mendapatkan perhatian khusus dalam pelayanan KB. Pada masa awal pandemi Covid-19, angka unmet need KB cenderung mengalami peningkatan. Berdasarkan laporan dari BKKBN 2020 tercatat sebanyak 36 juta peserta KB aktif pada bulan Maret mengalami penurunan menjadi 26 juta peserta dibulan April, sehingga terdapat selisih 10 juta akseptor yang tidak menggunakan alat kontrasepsi dan 25\% diantaranya merupakan Pasangan Usia Subur (PUS). Penurunan kepesertaan KB aktif ini dapat berdampak pada resiko terjadi Kehamilan Yang Tidak Diinginkan (KTD), maupun peningkatan "baby boom" pasca pandemi. Tujuan dari kegiatan ini adalah membantu PUS dalam memecahkan dan menemukan solusi terhadap permasalahan terkait KB serta memberikan layanan KB. Kegiatan ini dikemas dalam bentuk pendampingan konseling dan pelayanan KB gratis terutama bagi PUS yang tergolong unmet need. Dilakukan secara tatap muka dengan menerapkan protokol kesehatan yang ketat. Hasil kegiatan Pengabdian kepada Masyarakat ini yaitu dari 20 orang PUS yang melakukan konseling, sebanyak 15 orang $(75 \%)$, bersedia menjadi akseptor KB aktif sedangkan 2 orang $(10 \%)$ akan mendiskusikan kembali dengan pasangannya dan 3 orang lainnya (15\%) belum siap untuk menggunakan kontrasepsi.
\end{abstract}

Kata kunci: pendampingan; PUS; unmet Need KB; adaptasi kebiasaan baru

\begin{abstract}
The high number of unmet need is not only a family planning problem in Indonesia, but also in every part of the world. Unmet need target groups that need special attention. At the beginning of the Covid19 pandemic, the number of unmet need for family planning tends to increase.Reports from the BKKBN in 2020, from March to April there was a decrease in active family planning acceptors by 10 million participants and $25 \%$ of them are couples of childbearing age. This decrease in participation has an impact on the risk of unwanted pregnancies and an increase in the post-pandemic "baby boom". The purpose of this activity is to assist couples in solving and finding solutions to family planning problems and providing family planning services. This activity is packaged in the form of counseling assistance and free family planning services, especially for couples of childbearing age with unmet need. The results of this Community Service activity are from 20 people who did counseling, as many as 15 people $(75 \%)$, were willing to become active family planning acceptors while 2 people $(10 \%)$ would discuss again with their partners and 3 other people $(15 \%)$ were not ready to use contraception.
\end{abstract}

Keywords: accompaniment; couples of childbearing age; unmet need KB; new habit adaptation

\section{PENDAHULUAN}

Indonesia merupakan salah satu negara dengan jumlah penduduk terbanyak di dunia dan menempati urutan ke empat setelah China, India dan Amerika Serikat. Berdasarkan data worldometers Januari 2019 jumlah penduduk Indonesia sebanyak 269.536 .482 jiwa, dengan pertumbuhan penduduk $1.03 \%$ atau bertambah 2.742 .502 penduduk dibandingkan dengan tahun 2018 (Worldometer, 2020). Hal ini disebabkan karena masih tingginya Laju Pertumbuhan Penduduk (LPP)

Berbagai upaya telah dilakukan oleh pemerintah untuk menekan LPP salah satunya yaitu melalui program Keluarga Berencana. Program KB selain menjadi program nasional, juga menjadi salah satu target yang perlu dicapai dalam Sustainable Development Goals 
(SDG'S) yaitu pemenuhan hak kesehatan seksual dan reproduksi serta sosialisasi program penurunan kelahiran yang efektif dan efisien (BPS, 2014).

Salah satu permasalahan pada program KB yaitu masih tingginya kebutuhan $\mathrm{KB}$ yang tidak terpenuhi (unmet need). Unmet need KB adalah Wanita Usia Subur (WUS) dengan rentang usia 15-49 tahun yang tidak memakai alat kontrasepsi dengan alasan ingin anak nanti atau tidak ingin memiliki anak lagi, atau dalam kondisi hamil yang kehamilannya tidak diinginkan atau diinginkan nanti (dalam kurun waktu 2 tahun atau lebih) (BKKBN, 2017).

Di Indonesia, angka unmet need KB pada tahun 2012 sebesar 11,4\% (BKKBN, 2012), kemudian menurun menjadi $10,6 \%$ di tahun 2017 (BKKBN, 2018) dan kembali menurun pada tahun 2018 menjadi 10,14\% (BKKBN, 2019). Angka unmet need dari tahun ke tahun tersebut masih belum mencapai angka unmet need yang ditargetkan oleh BKKBN di dalam RENSTRA BKKBN 2020-2024 yaitu sebesar 7,4\% (BKKBN, 2020), sehingga Kelompok unmet need merupakan sasaran yang perlu menjadi perhatian dalam pelayanan program KB (Sariyati and Alfiana, 2013).

Pada masa awal Pandemi Covid-19 angka Unmet Need KB cenderung mengalami peningkatan. Menurut dr. Hasto Wardoyo, Sp.OG (K) selaku Kepala BKKBN menyatakan bahwa, penurunan penggunaan kontrasepsi pada bulan Februari hingga Maret 2020 mencapai $40 \%$, selain itu jumlah akseptor KB aktif yang tercatat pada bulan Maret yaitu sebesar 36 juta juga mengalami penurunan sebanyak 26 juta pada bulan April 2020, sehingga terdapat selisih 10 juta yang tidak menggunakan kontrasepsi dan $25 \%$ diatarananya merupakan Pasangan Usia Subur (PUS). Adapun penurunan penggunaan alat kontrasepsi berdasarkan jenis alkon antara lain implan turun dari 81.062 menjadi 51.536, suntik KB dari 524.989 menjadi 341.109, sedangkan pil KB turun 251.619 menjadi 146.767, kondom dari 31.502 menjadi 19.583, MOP (vasektomi) dari 2.283 menjadi 1.196, dan MOW (tubektomi) dari 13.571 menjadi 8.093. (BKKBN, 2020).

Peningkatan unmet need dimasa pandemi disebabkan beberapa hal antara lain yaitu, banyak fasilitas layanan yang tutup dan pelayanan KB dianggap bukan suatu hal yang bersifat emergency, sehingga tenaga medis lebih terfokus untuk menangani pandemi, tenaga kesehatan seperti Praktek Mandiri Bidan tidak memiliki alat pelindung diri (APD) yang lengkap, adanya himbauan pemerintah untuk berada di rumah saja yang menyebabkan akseptor KB tidak berani mengunjungi fasilitas kesehatan karena takut terinfeksi virus, serta diberlakukannya pembatasan sosial berskala besar.

Terhambatnya dalam mengakses fasilitas kesehatan terutama penggunaan alat kontrasepsi jangka panjang (MKJP) dapat menyebabkan terjadinya unwanted pregnancy dan mistimed pregnancy (Kehamilan Tidak Diinginkan) (Pembajeng et al., 2020),). Dalam hal ini, pemerintah sendiri telah melakukan berbagai upaya guna mengantisipasi peningkatan angka kehamilan dan kelahiran dimasa pendemi Covid-19. Sejak masa pertengahan bulan Mei 2020 lalu hingga tahun 2021, BKKBN telah melakukan pengontrolan dan peningkatan pasokan alat kontrasepsi pada berbagai wilayah di Indonesia guna melakukan antisipasi terhadap kurangnya ketersediaan alat kontrasepsi selama masa pandemik berlangsung (Ungaran \& Permana, 2020).

Sehubungan dengan permasalahan tersebut, pihak Poltekkes Kartini Bali memandang bahwa, urgensi pelaksanaan program KB di Masa Adaptasi Kebiasan Baru ini perlu dilaksanakan untuk mencegah terjadinya dampak unmet need yang tidak terkontrol. Adapun kegiatan ini yaitu Pendampingan Pada Pasangan Usia Subur Dalam Penggunaan Kontrasepsi Sebagai Upaya Menekan Unmet Need KB, sehingga secara tidak langsung dapat berkontribusi dalam menunjang pembangunan yang berkelanjutan serta menciptakan bonus demografi sebagai modal pertumbuhan ekonomi yang lebih pesat dimasa yang akan datang.

\section{METODE}

Kegiatan Pengabdian kepada Masyarakat (PKM) ini dilakukan di Praktek Mandiri Bidan Ni Ketut Nuriasih, S.ST.,MM, sekaligus sebagai mitra dalam kegiatan ini dengan sasaran Pasangan Usia Subur (PUS) dengan kriteria unmet need KB berjumlah 20 orang. Pelaksanaan pengabdian dilakukan sebanyak 3 kali. Metode pelaksanaan terdiri dari beberapa tahapan yaitu tahap persiapan, pelaksanaan, dan evaluasi.

Tahapan persiapan dilakukan dengan melakukan pendekatan dan kerjasama dengan mitra dalam pelaksanaan kegiatan pengabdian sekaligus menjelaskan tujuan dan tekhnik pelaksanaan. Disepakati dilakukan secara luring dengan menerapkan protokol kesehatan yang ketat, selain itu, meminta bantuan kepada mitra untuk menginformasikan kepada kelompok sasaran bahwa, akan dilakukan pendampingan berupa konseling dan pelayanan KB gratis sesuai dengan waktu dan tempat yang telah disepakati serta meminta 
daftar nama PUS yang ingin berpartisipasi dalam kegiatan ini, kemudian dibuatkan jadwal kedatangan untuk menghindari terjadinya kerumunan, mengingat masih dalam situasi pandemi covid-19. Selanjutnya mengurus birokrasi dan permohonan izin kepada pihak terkait.

Tahapan Pelaksanaan dimulai dari tanggal 19-24 April 2021. Pada hari pertama dan kedua dilakukan pendampingan konseling $\mathrm{KB}$, dimana konseling ini diutamakan bagi PUS yang ingin berkonsultasi dan tergolong unmet need. Tujuan dari konseling ini adalah untuk membantu partisipan dalam memecahkan masalah dan mendapatkan solusi terkait dengan permasalahan yang dihadapi oleh masing-masing PUS terkait dengan Keluarga Berencana. Dalam proses konseling juga diberikan penjelasan mengenai pentingnya penggunaan kontrasepsi, dampak dari unmet need, tujuan, manfaat, jenis-jenis kontrasepsi, kelebihan dan kekurang serta indikasi maupun kontraindikasi terhadap jenis alkon dengan menggunakan lembar balik Alat Bantu Pengambilan Keputusan (ABPK), untuk memudahkan partisipan memahami penjelasan yang diberikan. Setelah proses konseling, partisipan diberikan kesempatan untuk bertanya terkait dengan hal-hal yang belum dimengerti, dan menanyakan kesediannya untuk menjadi akseptor KB aktif. Selanjutnya pada hari ke tiga sampai keenam difokuskan dalam pemberian pelayanan. Hal ini dimaksudkan agar pelaksanaan pelayanan lebih efektif dan waktu yang diberikan kepada partisipan lebih fleksibel, mengingat tidak semua partisipan bisa hadir sesuai dengan jadwal yang ditentukan oleh karena adanya kesibukan dan kepentingan yang berbeda-beda.

\section{HASIL DAN PEMBAHASAN}

Program Pengabdian kepada Masyarakat (PKM) yang dilaksanakan di Wilayah Kecamatan Denpasar Timur tepatnya di PMB mitra, mendapat respon dan dukungan positif dari seluruh perangkat desa, tokoh agama dan masyarakat. Sasaran utama dalam kegiatan ini adalah PUS dengan unmet need $\mathrm{KB}$ yang berjumlah 20 orang, dimana pada kegiatan ini hanya bisa dihadiri oleh pihak istri oleh karena suami memiliki kesibukan. Sebelum dimulainya kegiatan, dilakukan komunikasi secara daring yaitu melalui Whatshap group (WAG) untuk menginformasikan terkait dengan pelaksanaan kegiatan dan digunakan sebagai tempat berbagi pengalaman terkait penggunaan alat kontrasepsi. Adapun distribusi frekuensi peserta PkM yang merupakan PUS tergolong kelompok unmet need yaitu sebagai berikut:
Tabel 1. Distribusi Frekuensi Karakteristik Peserta PkM Berdasarkan Pendidikan dan Pekerjaan

\begin{tabular}{ccc}
\hline Kategori & $\begin{array}{c}\text { Frekuensi } \\
(\mathbf{f})\end{array}$ & $\begin{array}{c}\text { Presentase } \\
(\mathbf{\%})\end{array}$ \\
\hline & Pendidikan & \\
\hline SD & 2 & 10 \\
\hline SMP & 2 & 10 \\
\hline SMA & 6 & 30 \\
\hline PerguruanTinggi & 10 & 50 \\
\hline Total & $\mathbf{2 0}$ & $\mathbf{1 0 0}$ \\
\hline & Pekerjaan & \\
\hline Bekerja & 15 & 75 \\
\hline Tidak Bekerja & 5 & 25 \\
\hline Total & $\mathbf{2 0}$ & $\mathbf{2 0}$ \\
\hline
\end{tabular}

Pada tabel 1 dapat dilihat bahwa, setengah dari peserta PkM berlatar belakang pendidikan Perguruan Tinggi (PT) yaitu 10 orang $(50 \%)$ sedangkan berdasakan pekerjaan, sebagian besar partisipan bekerja, sebanyak 15 orang $(75 \%)$. Pendidikan dan pekerjaan merupakan salah satu faktor yang dapat mempengaruhi kejadian unmet need. Tingginya proporsi unmet need KB pada ibu yang berpendidikan tinggi, cenderung tinggi (Rustini, 2017). Pada hasil analisis jawaban partisipan didapatkan bahwa, ibu dengan pendidikan tinggi lebih mampu untuk beripikir rasional terkait efek samping yang ditimbulkan dari suatu alat kontrasepsi, sehingga enggan untuk menggunakan KB. Begitupula pada status pekerjaan ibu, dimana dalam hal ini, ibu yang bekerja cenderung memiliki kesibukan, yang menyebabkan kurangnya kesempatan dalam mengakses fasilitas layanan kontrasepsi.

Sebelum dilaksanakan kegiatan pelayanan $\mathrm{KB}$, terlebih dahulu partisipan difasilitasi untuk mendapatkan pendampingan konseling, guna membantu partisipan untuk memecahkan dan memberikan solusi terkait penggunaan alat kontrasepsi, sehingga dapat meningkatkan kesadaran dan kesedian partisipan maupun pasangan untuk menjadi akseptor KB aktif.

Tabel 2. Distribusi Frekuensi Kepesertaan KB Aktif

\begin{tabular}{ccc}
\hline Kategori & $\begin{array}{c}\text { Frekuensi } \\
(\mathrm{f})\end{array}$ & $\begin{array}{c}\text { Presentase } \\
(\%)\end{array}$ \\
\hline Bersedia & 15 & 75 \\
\hline $\begin{array}{c}\text { Tidak } \\
\text { Bersedia }\end{array}$ & 2 & 10 \\
\hline Ragu-ragu & 3 & 15 \\
\hline Total & 20 & 100 \\
\hline
\end{tabular}

Dari hasil pendampingan konseling, didapatkan sebagian besar yaitu 15 orang 
(75\%) bersedia untuk menjadi akseptor KB aktif yang dapat dilihat dari keikutsertaan partisipan mendapatkan layanan KB gratis, ini juga dapat digunakan sebagai evaluasi keberhasilan pengabdi dan mitra dalam memberikan edukasi serta pemahaman partisipan terkait pentingnya penggunaan kontrasepsi, sehingga dapat mengubah sikap dan perilaku partisipan yang sebelumnya tidak ber-KB, namun saat ini bersedia menjadi peserta KB. Konseling merupakan salah satu cara untuk meningkatkan pengetahuan karena komunikasi yang diterapkan adalah komunikasi dua arah, sehingga PUS akan bebas mengungkapkan perasan dan pikirannya yang beroreantasi pada kenyataan atau permasalahannya, saling percaya, saling perhatian, saling memahami, dan saling mendukung.

Hasil kegiatan ini juga menunjukkan sikap dan perilaku PUS yang tidak bersedia untuk menggunakan kontrasepsi dengan alasan belum siap dan takut akan efek samping yang ditimbulkan. Dalam pelaksanaan program KB faktor yang mempengaruhi pemilihan kontrasepsi antara lain efektifitas, keamanan, frekuensi pemakaian, efek samping (Musdalifah, et al, 2016). Selain itu beberapa partisipan juga belum memberikan keputusan dan mengatakan masih ragu terhadap keinginannya untuk ber-KB, sehingga meminta izin untuk berdiskusi terlebih dahulu dengan suaminya. Hal ini dapat terlihat bahwa peran suami sebagai pemegang keputusan merupakan salah satu determinan dalam tercapainya keberhasilan Program KB. Adanya dukungan suami dapat meningkatkan keikutsertaan dan kepercayaan diri istri untuk mau menggunakan alat kontrasepsi. Menurut Putri et al, (2021), lbu yang mendapatkan dukungan buruk dari suami berpeluang mengalami kejadian unmet need KB 16,4 kali lebih besar dibandingkan dengan WUS yang mendapat dukungan baik dari suami, sehingga dalam hal ini, ketepatan metode dalam proses konseling sangat mempengaruhi keputusan ibu dalam menggunakan alat kontrasepsi, begitupula kualitas konseling juga memiliki efek mendalam pada seberapa efektif (konsisten dan benar) metode kontrasepsi tersebut akan digunakan (WHO, 2016).

Pada masa adaptasi kebiasaan baru, kebutuhan akan pelayanan kontrasepsi sangat dibutuhkan terlebih bagi PUS. Kesulitan ekonomi dalam situasi pandemi saat ini, juga menjadi salah satu faktor untuk meningkatnya kejadian unmet need, sehingga dengan adanya pelayanan KB gratis dan program pendampingan yang dilakukan oleh pengabdi, dapat membantu PUS untuk memenuhi kebutuhannya dalam penggunaan kontrasepsi tanpa harus memikirkan biaya yang harus dikeluarkan untuk mendapatkan layanan tersebut.

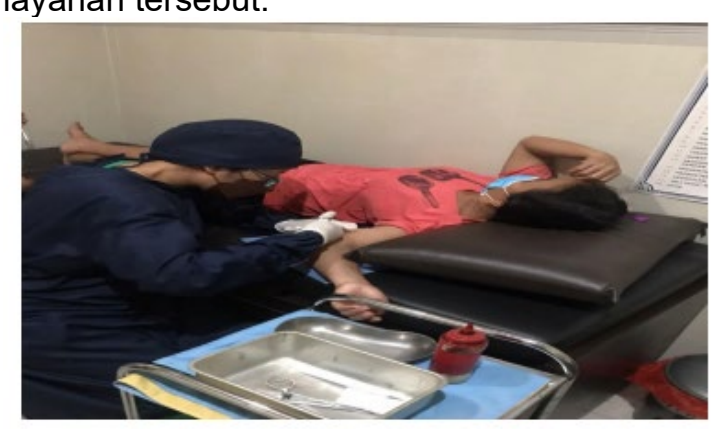

Gambar 1. Dokumentasi Pelayanan KB

\section{SIMPULAN DAN SARAN}

Pengabdian kepada Masyarakat mengenai Pendampingan Pada Pasangan Usia Subur Dalam Penggunaan Kontrasepsi Sebagai Upaya Menekan Unmet Need KB Di Masa Adaptasi Kebiasaan Baru ini telah terlaksana dengan baik, secara luring dengan penerapan protokol kesehatan. Hasil yang didapatkan pada kegiatan ini yaitu terjadinya peningkatan kesadaran dan perubahan perilaku pada PUS setelah diberikan pendampingan konseling berupa kesedian partisipan untuk menggunakan alat kontrasepsi melalui pelayanan KB yang diberikan secara gratis terutama pada PUS dengan status unmet need. Diharapkan PUS dapat mempertahankan untuk menggunakan kontrasepsi agar tidak terjadi drop out yang berdampak pada tingginya kejadian unmet need dan bagi partisipan yang belum memutuskan dan bersedia untuk menggunakan kontrasepsi dapat mencari dukungan dari tokoh agama maupun sumber terpercaya, sehingga dapat meningkatkan pemahaman dan self efficacy partisipan untuk menggunakan kontrasepsi, guna membantu upaya pemerintah dalam menurunkan AKI dan AKB terutama dalam masa adaptasi kebiasaan baru.

\section{UCAPAN TERIMAKASIH}

Pengabdi mengucapkan terima kasih kepada subyek binaan yaitu PUS yang berada di Wilayah Kecamatan Denpasar Timur, aparat desa dan para mitra yang senantiasa membantu, mendukung dan ikut berpartisipasi dalam kegiatan yang dilakukan oleh pengabdi. Tidak lupa pula pengabdi mengucapkan terima kasih kepada Yayasan Kartini Bali yang telah memberikan dana hibah demi terlaksananya kegiatan Pengabdian kepada Masyarakat ini. 


\section{DAFTAR RUJUKAN}

BKKBN. (2012). Survei Demografi dan Kesehatan Indonesia (SDKI). Jakarta

BKKBN. (2017). Survei Demografi dan Kesehatan Indonesia (SDKI). Jakarta

BKKBN. (2019). Survei Demografi dan Kesehatan Indonesia (SDKI). Jakarta

BKKBN. (2020) Rencana Strategis BKKBN 2020-2024. Jakarta.

BPS. (2014). Kajian Indikator Sustainable Development Goals (SDGs). Jakarta

Mufdlilah, M., \& Aryekti, K. (2016). Dukungan Suami Terhadap Kejadian Drop Out Bagi Akseptor Keluarga Berencana (KB) di Desa dan Kota Di Daerah Istimewa Yogyakarta. Musãwa Jurnal Studi Gender dan Islam, 15(1): 113-124

Puteri N, Noor M, Arifin S. (2019). Hubungan Dukungan Suami dan Pola Komunikasi Suami Istri dengan Penggunaan Metode Kontrasepsi Jangka Panjang (MKJP). Homeostasis. 2(1):147-54.

Rustina, S. (2017). Faktor - Faktor Yang Berhubungan Dengan Kejadian Unmet Need Pada Pasangan Usia Subur (PUS) Di Kelurahan Ngupasan Yogyakarta. Skripsi. Yogyakarta: Universitas 'Aisyiyah

Sariyati, S, Alfiana, H. (2013). Gambaran Keinginan Unmet Need Terhadap Pelayanan KB di Kota Yogyakarta. Jurnal Ners dan Kebidanan Indonesia. No 1. Volume 1. 2354-7642.

Ungaran, K., \& Permana, D. A. (2020). Penjelasan BKKBN soal Kehamilan Meningkat di Tengah Pandemi Covid19.https://regional.kompas.com/read/2 020/07/24/18243691/penjelasanbkkbn soal-kehamilan-meningkat-di-tengahpandemi-covid-19.

World Health Organization. (2016). Selected practice recommendations for contraceptive use (3rd ed.). Geneva: WHO.

Worldometer (2020) Current World Population, 2020. Available at: https://www.worldometers.info/worldpopulation/ (Accessed: 20 November 2021). 